Personalidade Acadêmica Homenageada:

Florisbal de Souza Del'Olmo (Professor Convidado - UNICURITIBA)

\title{
O ATIVISMO JUDICIÁRIO E A PRISÃO APÓS CONDENAÇÃO EM SEGUNDA INSTÂNCIA
}

\section{VIVIANI HASSELMANN DE BASTOS}

Membro de pesquisa da instituição Faneesp - Faculdade Nacional de Educação e Ensino Superior do Paraná.

\section{OBJETIVOS DO TRABALHO}

Diante da omissão do Poder Legislativo brasileiro, no que se refere a assuntos que possam ser polêmicos na sociedade, por diversas vezes o Poder Judiciário é chamado a se manifestar a fim de sanar eventuais lacunas e acaba por legislar ao interpretar determinadas normas, extrapolando suas funções precípuas constantes na Constituição Federal do Brasil de 1988 e agindo de acordo com o chamado ativismo judicial.

Recentemente o Supremo Tribunal Federal admitiu, ainda que de forma não unânime, a prisão preventiva de acusados após a confirmação da condenação na segunda instância, ao julgar o Habeas Corpus no 126.292/SP. Tal decisão foi polêmica uma vez que fere o princípio da presunção de inocência instituído na Constituição Federal.

O presente trabalho não tem a pretensão de esgotar o tema, busca analisar a ocorrência do ativismo judicial no que tange ao entendimento da Suprema Corte ao admitir o início do cumprimento da pena a partir da condenação em segunda instância. 


\section{Personalidade Acadêmica Homenageada:}

Florisbal de Souza Del'Olmo (Professor Convidado - UNICURITIBA)

\section{METODOLOGIA UTILIZADA}

A fim de atingir o objetivo proposto, serão aplicados os métodos dedutivo e dialético, a partir de revisão bibliográfica sobre o ativismo judicial, partindo da análise dos diferentes pontos de vista expostos pelos Ministros em seus votos no HC n126.292, à luz dos princípios constitucionais relacionados.

\section{REVISÃO DE LITERATURA}

$\mathrm{Na}$ vigência da atual Constituição, o Poder Judiciário teve seu papel ampliado diante da sociedade brasileira, sendo que o poder constituinte originário atribuiu ao Judiciário, expressamente no artigo 102 da Carta Magna, a função de guardião dos valores constitucionais, assegurando mecanismos de proteção ao texto constitucional.

Diante da omissão do legislativo em diversas matérias, a Suprema Corte tem sido provocada a se manifestar e, muitas vezes, não se limita a declarar a omissão legislativa, indo além ao impor obrigações aos demais Poderes e aos administrados em geral. O que pode ser entendido como uma intromissão do Poder Judiciário no âmbito da autonomia entre os Poderes, ferindo assim a harmonia que deve existir entre eles, corolário instituído no Art. $2^{\circ}$ da Constituição Federal de 1988. Esta atuação do judiciário é tratada na doutrina como Ativismo Judicial.

Para a professora Vanice Regina Lírio do Valle ${ }^{1}$, o conceito de ativismo social é:

a) a prática dedicada a desafiar atos de constitucionalidade defensável emanados de outros poderes; b) estratégia de não aplicação dos precedentes; c) conduta que permite aos juízes legislar "das salas das sessões"; d) afastamento dos cânones metodológicos de interpretação; e) julgamento para alcançar resultados pré-determinados.

\footnotetext{
1 VALLE, Vanice Regina Lírio do. Ativismo Jurisprudencial e o Supremo Tribunal Federal. Laboratório de Análise Jurisprudencial do STF. Curitiba: Juruá. 2009, p. 21.
} 


\section{Personalidade Acadêmica Homenageada:}

Florisbal de Souza Del'Olmo (Professor Convidado - UNICURITIBA)

Já para o Ministro Luís Roberto Barroso², o ativismo judicial é uma atitude ou uma escolha do magistrado na maneira de interpretar as normas constitucionais, de forma a expandir seu alcance e normalmente associado a uma omissão do Poder Legislativo.

As principais críticas ao ativismo judicial se referem à ilegitimidade democrática dos magistrados para insurgirem-se contra atos legalmente instituídos pelos poderes eleitos pelo povo, ou seja, a atuação do judiciário atuando como legislador negativo, ao invalidar atos dos poderes legislativos ou executivos; e como legislador positivo, ao interpretar normas e princípios e lhe atribuírem juízo de valor, conforme entendimento de Vicente Paulo Almeida ${ }^{3}$. Assim haveria uma intromissão do Poder Judiciário nos demais poderes, ferindo o princípio constitucional da separação dos poderes, bem como o Estado Democrático de Direito.

Ainda conforme ALMEIDA ${ }^{4}$, os argumentos favoráveis à prática do ativismo judicial se baseiam em um fundamento jurídico, de que os magistrados agem de acordo com a Constituição ao interpretarem e fazerem valer as cláusulas abertas e princípios constitucionais, agindo de maneira a garantir a vontade soberana do povo, que em Assembleia Constituinte assim determinou; e um fundamento filosófico, quando os magistrados devem decidir entre os direitos fundamentais e o interesse da maioria, muitas vezes em situações de conflito aparente, agindo como verdadeiro guardião do Estado Constitucional Democrático. Este que é fruto da ideia de constitucionalismo, que representa a limitação e o respeito aos direitos fundamentais, em conjunto com a ideia de democracia, que por sua vez representa a soberania do povo.

No julgamento do Habeas Corpus ํㅜ 126.292/SP, a Suprema Corte, por sete votos a quatro, firmou entendimento no sentido de admitir a prisão após confirmação da condenação em segunda instância, contrariando os princípios constitucionais da presunção da inocência e do devido processo legal.

\footnotetext{
${ }^{2}$ BARROSO, Luís Roberto. Judicialização, Ativismo Judicial e Legitimidade Democrática, p.6. Disponível em: <http://www.cnj.jus.br/eadcnj/mod/resource/view.php?id=47743>. Acesso em 12/05/2018.

${ }_{3}$ ALMEIDA, Vicente Paulo. Ativismo Judicial. 2011. Disponível em: <https://jus.com.br/artigos/19512/ativismo-judicial/1 >. Acesso em: 09/05/2018.

${ }^{4}$ Id.
} 


\title{
Personalidade Acadêmica Homenageada:
}

Florisbal de Souza Del'Olmo (Professor Convidado - UNICURITIBA)

O relator do processo foi o Ministro Teori Zavascki que se posicionou favoravelmente à prisão provisória, fundamentado seu voto no argumento de que a execução da pena após confirmação da condenação em segunda instância não afronta o princípio da presunção de inocência, "na medida em que o acusado foi tratado como inocente no curso de todo o processo ordinário criminal, observados os direitos e as garantias a ele inerentes". O relator fundamenta que:

\begin{abstract}
A retomada da tradicional jurisprudência, de atribuir efeito apenas devolutivo aos recursos especial e extraordinário (como, aliás, está previsto em textos normativos) é, sob esse aspecto, mecanismo legítimo de harmonizar o princípio da presunção de inocência com o da efetividade da função jurisdicional do Estado.
\end{abstract}

Tal posição foi acompanhada pelos Ministros Edson Fachin, Luís Roberto Barroso, Luiz Fux, Dias Toffoli, Carmen Lúcia e Gilmar Mendes.

O argumento contrário, apresentado pelos Ministros Marco Aurélio, Celso de Mello, Ricardo Lewandoski e Rosa Weber, foram baseados na alegação de que é incompatível a execução da pena antes do trânsito em julgado, uma vez que a presunção de inocência se encontra expressa de forma clara na Constituição Federal, não deixando espaço para uma interpretação diversa.

A Constituição Federal do Brasil de 1988 instituiu o princípio da presunção de inocência" ${ }^{5}$ que se trata de um desdobramento da máxima romana "in dubio pro reo", que determina que a reponsabilidade pela prova do delito seja do acusador e que eventual dúvida sobre a culpabilidade conduza à absolvição, e prevê ainda que o acusado seja protegido da publicidade excessiva do processo e consequente estigmatização precoce.

É por força deste princípio que normas que imponham a prisão do acusado antes do trânsito em julgado, ressalvadas as previsões de prisões cautelares, seriam incompatíveis com a Constituição Federal, supondo-se, assim, que não foram recepcionados os dispositivos do Código Penal que previam o recolhimento do réu à prisão enquanto aguarda o julgamento pelo Tribunal do Júri ou da apelação.

${ }^{5}$ LVII, que "ninguém será considerado culpado até o trânsito em julgado de sentença penal condenatória" (CONSTITUIÇÃO FEDERAL, 1988, ART. 5) 


\section{Personalidade Acadêmica Homenageada:}

Florisbal de Souza Del'Olmo (Professor Convidado - UNICURITIBA)

O ministro do STF, Gilmar Mendes ${ }^{6}$, já se posicionou no sentido de que a prisão preventiva automática constitui "grave atentado contra a própria ideia de dignidade humana", este entendimento ia ao encontro do que se empregava desde o julgamento em plenário do HC 84.078/MG, de 2009.

O princípio da presunção de inocência está estritamente ligado ao princípio do devido processo legal", que advém do termo em inglês "due process of law", referenciado na lei inglesa denominada Statute of Westminster of the Liberties of London, de 1354, e inserindo em diversos ordenamentos jurídicos desde então ${ }^{8}$.

No direito brasileiro, a cláusula constitucional prevê a possibilidade efetiva das partes terem acesso à justiça, deduzindo pretensão e defendendo-se de forma ampla. A ideia geral é de um processo justo, pressupondo a isonomia entre as partes, o direito ao contraditório e à ampla defesa, a presunção de inocência, entre outros fundamentos, conforme Nery e Abboud ${ }^{9}$.

\section{TÓPICOS CONCLUSIVOS}

A mudança no posicionamento da Suprema Corte em relação à prisão após condenação em segunda instância pode ser vista como uma decisão de alta carga política, na medida em que amplia a interpretação de uma regra bastante clara presente na Carta Magna, ainda que fundamentada em uma tentativa ao combate à impunidade e redução da criminalidade.

A execução provisória da pena pode ser encarada como uma forma de fazer valer a decisão tanto do juiz de primeira instância, quanto do tribunal de segunda instância, além de buscar um retorno ao prestígio da função dos Tribunais Superiores de guardiães da Constituição e não meramente de órgãos de terceira ou quarta instâncias. Porém, ainda assim, esse posicionamento é uma afronta à

\footnotetext{
${ }^{6}$ MENDES, Gilmar Ferreira. Jurisdição Constitucional. O Controle Abstrato de Normas no Brasil e na Alemanha. Saraiva. 2009. 5a Ed. Pág. 296.

7 "LIV - ninguém será privado da liberdade ou de seus bens sem o devido processo legal;" (CONSTITUIÇÃO FEDERAL, 1988, ART. 5)

${ }^{8}$ NERY JR., Nelson e ABBOUD, Georges. Direito Constitucional Brasileiro - Curso Completo. 1 $1^{\text {a }}$ Ed. em e-book. Editora Revista dos Tribunais Ltda. 2017.

${ }^{9}$ Id.
} 
Personalidade Acadêmica Homenageada:

Florisbal de Souza Del'Olmo (Professor Convidado - UNICURITIBA)

Constituição, uma vez que a presunção de inocência é cláusula de aplicabilidade plena, cuja interpretação não deveria ser diversa da estritamente expressa no texto constitucional.

Desta forma, pode-se identificar claramente a ocorrência do fenômeno do ativismo judicial em sua forma positiva no posicionamento firmado a partir do julgamento nos autos do Habeas Corpus no 126.292, uma vez que admitiu interpretação da norma de forma diversa à pretendida pelo poder constituinte $e$, agindo assim, o Superior Tribunal Federal extrapolou o limite de suas funções ao legislar, criando norma que vincula toda sociedade.

\section{REFERÊNCIAS}

BRASIL. Constituição da República Federativa do Brasil: promulgada em 05 de outubro de 1988. Brasília: Senado Federal.

ALMEIDA, Vicente Paulo. Ativismo Judicial. 2011. Disponível em: <https://jus.com.br/artigos/19512/ativismo-judicial/1 >. Acesso em: 09/05/2018.

BARROSO, Luís Roberto. Judicialização, Ativismo Judicial e Legitimidade Democrática, $\quad$ p. 6.6 Disponível $<$ http://www.cnj.jus.br/eadcnj/mod/resource/view.php?id=47743>. Acesso em $12 / 05 / 2018$.

MENDES, Gilmar Ferreira. Jurisdição Constitucional. O Controle Abstrato de Normas no Brasil e na Alemanha. Saraiva. 2009. 5ª Ed. Pág. 296.

NERY JR., Nelson e ABBOUD, Georges. Direito Constitucional Brasileiro Curso Completo. $1^{\underline{a}}$ Ed. em e-book. Editora Revista dos Tribunais Ltda. 2017.

VALLE, Vanice Regina Lírio do. Ativismo Jurisprudencial e o Supremo Tribunal Federal. Laboratório de Análise Jurisprudencial do STF. Curitiba: Juruá. 2009. 